\title{
SALT TOLERANCE OF OCIMUM BASILICUM CV. GENOVESE USING SALICYLIC ACID, SEAWEED, DRY YEAST AND MORINGA LEAF EXTRACT
}

\author{
G.T. Mousa; S.S.A. Abdel-Rahman; E.Y. Abdul-Hafeez and Nesma M. Kamel \\ Ornamental Plants and Landscape Gardening Dept., Fac. Agric., Assiut Univ., Egypt
}

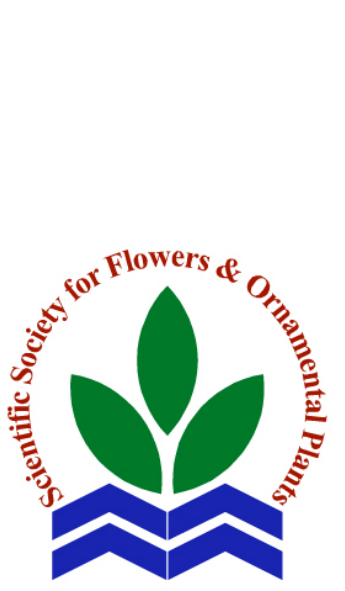

Scientific J. Flowers \& Ornamental Plants, 7(2):131-151 (2020).

Received:

21/5/2020

Accepted:

9/6/2020

ABSTRACT: To improve the salt tolerance of Genovese cultivar of sweet basil (Ocimum basilicum L.) plants, an experiment was conducted to evaluate the impact of certain growth substances (salicylic acid, seaweed extract, dry yeast and moringa leaf extract) on growth, volatile oil percentage and yield as well as chemical constituents under saline water irrigation stress conditions (control, 1000, 2000 and $4000 \mathrm{ppm} \mathrm{NaCl}$ ). The obtained results revealed that the higher salinity levels (2000 and $4000 \mathrm{ppm} \mathrm{NaCl)} \mathrm{caused} \mathrm{significant}$ decreases in vegetative growth measurements of basil plants compared to control and the lowest salinity level (1000 ppm NaCl). Maximum reduction was observed at $4000 \mathrm{ppm} \mathrm{NaCl}$ which showed higher increase of the total phenolics and free proline contents. All recoded parameters were enhanced for plants grown under $1000 \mathrm{ppm} \mathrm{NaCl}$. Seaweed extract was superior than other treatments in enhancing the plant tolerance to salinity which appeared in the significantly increasing of growth and volatile oil content of basil. Phenolics and proline contents were increased with salicylic acid treatment comparing with other ones. The best combination recommended as a result of the current study is treating basil plants with seaweed extract under low salinity level (1000 ppm) for improving the growth and volatile oil parameters.

Key words: Ocimum basilicum L., salinity stress, salicylic acid, seaweed, dry yeast, moringa leaf extract.

\section{INTRODUCTION}

Sweet basil (Ocimum basilicum L.) is known as a member of Lamiaceae family and appreciated as an aromatic spice and medicinal plant (Koba et al., 2009). It is an aromatic plant commonly cultivated in all parts of the world. Sweet basil is native to India, southern Asia and Middle East. Cultivated extensively in southern, central and Eastern Europe and North Africa (Singh and Panda, 2005). Economically, it is important as a source of essential oils, medicines and ornamentals. There are 150 to 160 species belongs to this genus broadly dispersed over the warm regions of the world (Evans, 2001). Basil is a multipurpose plant with great benefits in pharmaceutical, fragrance and food industries. Medicinally, this plant and its volatile oil have long been used to treat nausea, mental fatigue colds, dysentery and rhinitis. The main active components of sweet basil oil have been characterized as terpenoids and phenyl propane derivatives (Hassan et al., 2010).

Salinity stress is a main of the major limitation factors to crop productivity (arid and semiarid regions). The salt stress has negative effects on plant growth and development by modifying physiological and cellular processes (Mondal and Kaur, 2017). Excessive salts in soil reduce the availability of water, inhibit metabolic processes and affect osmotic balance, nutrient composition and hydraulic conductivity resulting in weak 


\section{G.T. Mousa et al.}

growth and productivity of plants (AlKaraki, 2001). Salinity not just lowers the agricultural production of most crops, but also, affects soil physicochemical characteristics (Srivastava and Kumar, 2015). Many strategies like plant growth biostimulants were studied to reduce the deleterious effects of salts on plants. Biostimulant known as any substance or microorganism applied to plants aiming to improve nutrition efficiency, crop quality traits, regardless of its nutrients content and abiotic stress tolerance (Patrick, 2015). Low salinity level (1000 ppm) significantly increased plant height, fresh and dry weights of the herb, number of branches/plant, oil \% and oil yield of all studied sweet basil cultivars. High salinity level (4000 ppm) caused significant reduction in all studied parameters (Abdel-Rahman et al., 2011).

Salicylic acid known as a plant growth regulator and endogenous signaling molecule, which is involved in different physiological processes in plants. Since, it plays a great role in growth regulation, photosynthesis, inhibition of fruit ripening, stomatal conductance, nutrient uptake, plant water relations and mechanisms of plant resistance and tolerance to biotic and abiotic stresses (Bagherifard et al., 2015). Several studies have been carried out using salicylic acid as a mitigator of the impacts of salinity on basil plants. Da Silva et al. (2018) revealed that the increase of electrical conductivity of irrigation water from 0.5 to $6.0 \mathrm{dS} / \mathrm{m} \mathrm{NaCl}$ reduced the growth (plant height, leaf number, stem diameter and leaf area) and phytomass of Ocimum basilicum L. cv. Cinnamon. Salicylic acid at rates up to $1.0 \mathrm{mM}$ positively affected most of the variables analyzed under salinity conditions. Karalija and Parić (2017) pointed out that foliar application of salicylic acid at rates of $0.01,0.1$ and $1.0 \mathrm{mM}$ resulted in an increase in morphological parameters and secondary metabolites production such as proline, polyphenols, soluble sugar and protein contents as well as peroxidase activity in basil (Ocimum basilicum L.) under saltine conditions. Delavari et al., (2010) found that photosynthetic pigments in Ocimum basilicum L. leaves were decreased in response to high salinity, but the lipid peroxidation and soluble sugars increased. Exogenous SA application, especially at 0.01 $\mathrm{mM}$ could reduce the adverse impacts of salinity on all measured parameters.

Seaweed extracts (SWE) as a biostimulants are emerging as commercial formulations for use as plant growth promoting factors and a method to improve tolerance to salinity, heat and drought. Algal extracts target a number of pathways to increase tolerance under stress. Seaweeds are red, green and brown macro algae that represent $10 \%$ of marine productivity (Battacharyya et al., 2015). Seaweed provides an excellent source of bioactive compounds such as carotenoids, protein, essential fatty acids, vitamins, amino acids, minerals and growth promoting substances (Bhaskar and Miyashita, 2005). Numerous studies have confirmed a wide range of beneficial effects of seaweed extract on growth and flowering of medicinal and aromatic plants. Shehata and Nosir (2019) cleared that spraying sweet basil plants $(O$. basilicum, L.) with seaweed extract (SWE) exhibited higher tolerance to high salinity as compared to unsprayed plants. Foliar application of seaweed extract at 100 and $200 \mathrm{ppm}$ resulted in higher values of plant height, shoot length, branch number/plant compared to unsprayed plants or those sprayed with lowest seaweed concentration (50 ppm) under high salinity levels (2000 and $4000 \mathrm{ppm} \mathrm{NaCl}$ ). They added that spraying basil plants with seaweed extract (SWE) at 50, 100 and 200 ppm significantly increased chlorophyll a, chlorophyll b and carotenoids contents as well as essential oil $\%$ in basil leaves as compared to unsprayed plants under high salinity levels (2000 and 4000 ppm NaCl). Mohamed et al. (2016) stated also that the application of SWE at 2 $\mathrm{ml} \mathrm{L}^{-1}$ significantly increased plant height, number of branches, fresh and dry weight of basil (O. basilicum, L. cv. Genovese) compared to the control. 
Active dry yeast (Y) has been given much attention as they are beneficial to plant growth and yield of crops under field inoculation. Active dry yeast is a natural safety bio-fertilizer causes various promoted effects on plants. It is considered as a natural source of cytokinins which stimulates cell division and enlargement as well as the synthesis of protein, nucleic acid and $\mathrm{B}$ vitamin (Amer, 2004). Several investigations were carried out on different experiments dealing with active dry yeast spray and its beneficial effect on growth and yield of medicinal and aromatic plants. Nassar et al. (2015) studied the effect of foliar spray with yeast extract on vegetative growth and yield of basil plants. The obtained results revealed that foliar application with yeast extract at 2, 4 and 8 g/l significantly increased all investigated morphological characters of vegetative growth and yield of fresh herb per plant at full blooming stage. Hamouda et al. (2012) demonstrated that spraying sweet basil (O. basilicum, L.) plants with yeast extract at 10, 20 and $30 \mathrm{~g} / \mathrm{l}$ resulted in a stimulation in growth characteristics in term of plant elongation, branching and fresh herb as well as the biomass of leaves and stems and dry matter production. The highest values of all vegetative growth characteristics studied were obtained from plants sprayed with yeast at $30 \mathrm{~g} / \mathrm{l}$. They also indicated that treating basil plants with yeast at 20 or $30 \mathrm{~g} / \mathrm{l}$ produced the highest oil percentage and oil yield as well as improving oil quality by decreasing estragole content in the oil compared to the control and other treatments.

Moringa leaf extract (MLE) is one of such alternatives, being studied to ascertain its influence on growth and yield of several crops, thus can be promoted among farmers as a possible supplement or substitute to inorganic fertilizers (Phiri, 2010). It is known as one of the world most useful trees, as almost all parts of the tree has an impressive impact of food, medicine and industrial process (Moyo et al., 2011). Hassanein et al. (2019) indicated that spraying sweet basil (O. basilicum L. cV.
Cispum) plants with either Moringa oleifera or $M$. peregrina leaf extracts resulted in a significant increase in vegetative growth parameters like leaf area, shoot length, shoot fresh and dry weight, number of branches, root length and root dry weight in basil plants compared to unsprayed ones. They also caused a significant increase of anthocyanin, total carbohydrates and superoxide dismutase in basil leaves compared to the untreated plants under salt stress conditions. Proline content was increased when plants irrigated with saline water compared to the untreated plants. Spraying basil plants with either Moringa oleifera or $M$. peregrena leaf extracts caused a significant reduction in proline content compared to the control under salt stress conditions.

The current study aiming to investigate the effects of salicylic acid as well as seaweed extract, dry yeast and moringa leaf extract on the growth, yield and volatile oil content of sweet basil (O. basilicum cv. Genovese) plants grown under salt stress conditions.

\section{MATERIALS AND METHODS}

The present study was conducted during the two successive seasons of 2017 and 2018 at Farm of Floriculture, Faculty of Agriculture, Assiut University, Assiut Governorate, Egypt. The main objective was to investigate the effect of foliar applications of salicylic acid, seaweed extract, active dry yeast and Moringa oleifera leaf extract on growth, yield and volatile oil content of sweet basil growing under salt stress conditions.

The experiment included 20 treatments which presented the combination between four salinity levels (control "tap water", 1000, 2000 and $4000 \mathrm{ppm} \mathrm{NaCl}$ ) and four growth substances: salicylic acid (SA); seaweed extract (SWE); dry yeast (Y) and Moringa oleifera leaf extract (MLE) in addition to control (untreated plants). The treatments were arranged in a split-plot design, with four replicates. The four salinity 


\section{G.T. Mousa et al.}

levels represented as main plots, while the growth substances represented sub-plots. Seeds of sweet basil (O. basilicum L. cv. Genovese) were obtained by Enza Zadden Company, Germany. At the middle of March 2017 and 2018, basil seeds were planted in earthenware pots $15 \mathrm{~cm}$ diameter. Five seeds were planted in each one. Pots were filled with clay loam soil. After 45 days from seed cultivation, uniform seedlings were transplanted to earthenware pots of $30 \mathrm{~cm}$ diameter and $40 \mathrm{~cm}$ height with perforated bottoms. All pots were filled with clay soil. Physical and chemical properties of the soil used were determined according to the methods described by Jackson (1973) and shown in Table (1).

Seedlings were regularly irrigated with tap water for one week after transplanting, and then subjected to different saline water irrigation levels (control, 1000, 2000 and $4000 \mathrm{ppm} \mathrm{NaCl}$ ) and foliar application of control "tap water", 200 ppm salicylic acid, $3 \mathrm{ml} / \mathrm{l}$ seaweed extract, $4 \mathrm{~g} / \mathrm{l}$ dry yeast and 1000 ppm Moringa oleifera leaf extract. Each foliar application was repeated two times with 15 days intervals for each cut. The plants were fertilized by a commercially grade NPK fertilizer for two times with 15 days interval for each cut. Salicylic acid produced by El-Nasr Pharmaceutical Chemicals Co., Egypt was applied as a foliar spray at the concentration of 200 ppm. Seaweed extract produced by CHEMA Company, contains $\mathrm{Fe}, \mathrm{Zn}, \mathrm{Cu}, \mathrm{Mn}$ and $\mathrm{Mo}$ minerals, vitamins, enzymes, amino acids, sugars and plant hormones, it was added at 3 $\mathrm{ml} / \mathrm{l}$. Dry yeast was produced by Angel Yeast Co., Ltd., Egypt. It was applied at the concentration of $4 \mathrm{~g} / \mathrm{l}$. Fresh leaves of
Moringa oleifera were harvested from the Farm of Floriculture, Faculty of Agriculture, Assiut University from fully matured trees then air-dried, ground and extracted as follows: ethyl alcohol $80 \%$ was added to leaf powder (10:1) and the mixture was put for $48 \mathrm{~h}$ on the rotary shaker. Leaf extract was purified by filtering twice through Whatmann paper No. 1, then the extract was subjected to a rotary evaporator to fully evaporate alcohol. The applied concentration was at 1000 ppm MLE.

Plant samples were collected at $40 \%$ of flowering for each cut. Three cuts were done; the first one at the beginning of July and between each cut and another was 45 days. Data recorded were plant height $(\mathrm{cm})$, number of branches/plant, number of leaves/plant, fresh weight of herb/plant (g), dry weight of herb/plant (g), leaf area $\left(\mathrm{cm}^{2}\right)$ calculated using digital image processing technique as described by Patil and Bodhe (2011), essential oil percentage and essential oil yield/plant were determined according to (Guenther, 1961), total soluble phenolic compounds content appreciated as described by Vasco et al. (2008), and free proline as described by Bates (1973).

Collected data were subjected to statistical analysis of variance using the normal (F) test and the means separation were compared by using least significant difference (LSD) at 5\% level according to Snedecor and Cochran (1989).

\section{RESULTS AND DISCUSSION}

Collected data showed the influence of foliar application with natural and synthetic substances (SA, SWE, Y and MLE) on some vegetative growth characteristics of $O$.

Table 1. Some physical and chemical analysis of clay medium used at the beginning of the experiment (average of both seasons).

\begin{tabular}{|c|c|c|c|c|c|c|c|c|c|c|c|}
\hline \multirow{3}{*}{ Soil type } & \multicolumn{7}{|c|}{ Soluble ions (meq/100 g soil*) } & \multirow{3}{*}{$\begin{array}{l}\text { Soluble K } \\
\text { (mg/100 g } \\
\text { soil) }\end{array}$} & \multirow{3}{*}{$\mathbf{p H} \dagger$} & \multirow{3}{*}{$\begin{array}{c}\text { EC } \\
\mathrm{dS} \mathrm{m}^{-1}\end{array}$} & \multirow{3}{*}{$\begin{array}{c}\text { Organic } \\
\text { matter } \\
(\%)\end{array}$} \\
\hline & \multicolumn{4}{|c|}{ Cations } & \multicolumn{3}{|c|}{ Anions } & & & & \\
\hline & $\mathbf{C a}^{2+}$ & $\mathbf{M g}^{2+}$ & $\mathrm{Na}^{+}$ & $\mathbf{K}^{+}$ & $\mathrm{HCO}_{3}{ }^{-}$ & $\mathbf{C l}^{-}$ & $\mathrm{SO}_{4}=$ & & & & \\
\hline Clayey & 3.2 & 2.50 & 3.81 & 0.007 & 3.26 & 3.62 & 2.63 & 0.23 & 8.14 & 0.97 & 1.72 \\
\hline
\end{tabular}

* Soil-water extract (1:5); †Soil-water suspension (1:2.5). 
basilicum plants under salinity stress conditions during 2017 and 2018 seasons. As shown in Table (2), the tallest plants; 42.7 and $39.6 \mathrm{~cm}$ in the $1^{\text {st }}$ cut, 43.6 and $44.9 \mathrm{~cm}$ in the $2^{\text {nd }}$ cut and 39.2 and $40.0 \mathrm{~cm}$ in the $3^{\text {rd }}$ one were obtained by low salinity level ) $1000 \mathrm{ppm} \mathrm{NaCl}$ ) for the first and second seasons, respectively. The least values of plant height were reached by 4000 ppm $\mathrm{NaCl}$ in the first and second seasons. Second cut of basil recorded the highest values of plant height in comparison with the first and third one at the same salinity level (1000 ppm $\mathrm{NaCl}$ ) during both seasons. Seaweed extract significantly increased the plant height; 41.4 and $38.8 \mathrm{~cm}$ in the $1^{\text {st }}$ cut; 38.4 and $43.4 \mathrm{~cm}$ in the $2^{\text {nd }}$ cut and 38.2 and 38.8 $\mathrm{cm}$ in the $3^{\text {rd }}$ one in the two studied seasons, respectively comparing with the control and other treatments. Salicylic acid was similar in influence with seaweed extract and recorded the tallest basil plants for all cuts during both seasons, except for the third cut during the first season where the dry yeast ranked second $(36.4 \mathrm{~cm})$ after seaweed extract. The best interaction effect between salinity levels and applied treatments on plant height was obtained from plants sprayed with seaweed and irrigated with $1000 \mathrm{ppm} \mathrm{NaCl}$ during both seasons for all cuts. However, the least interaction was exhibited for the three cuts with the untreated plants grown under 4000 ppm salinity stress.

Number of main branches per plant was greatly enhanced in the plants grown under 1000 ppm of salinity comparing with the control and other levels of salinity (Table, 3). Third cut showed superiority than the other cuts for the plants under $1000 \mathrm{ppm}$ salinity and recorded 12.3 and 10.7 branch/plant during the first and second seasons, respectively. Seaweed extract significantly increased mean branch number per plant for all cuts during the two studied seasons. The superior impact was more pronounced as 11.7 and 11.8 branch/plant with the third plant cut sprayed with seaweed in comparison with other treatments in the two seasons, respectively. The highest values of main branch number were recorded due to the application of seaweed to plants grown under 1000 ppm salinity stress. These results are in agreement with those obtained by Abdel-Rahman et al. (2011), as they reported that low salinity level (1000 ppm) significantly increased plant height, fresh and dry weights of the herb, number of branches/plant, oil \% and oil yield of all studied sweet basil cultivars. On contrary, high salinity level (4000 ppm) caused significant reduction in all studied parameters.

The observed reduction in vegetative growth characteristics of $O$. basilicum under high salinity levels may be attributed to that salinity reduced cell size, cell turgor and number of cells per unit area (Greenway and Munns, 1980). The utilization of seaweed extract augments uptake of nutrients from the soil (Turan and Kose, 2004).

Data presented in Table (4) showed that irrigation of basil plants with the low salinity level (1000 ppm $\mathrm{NaCl}$ ) recorded the highest significant increase in number of leaves/plant compared to non-salinized plants and the other salinity levels in the both seasons. Obviously, the higher salinity levels (2000 and $4000 \mathrm{ppm} \mathrm{NaCl}$ ) badly affected number of leaves/plant in each cut. Third cut of plants grown under 1000 ppm of salinity, hold the highest leaf number (291.9 and 262.4 leaf/plant) during both seasons, respectively. Plants treated with seaweed resulted in significant increase in leaf number/plant for the three interval cuts in both seasons. Also, the third cut produced the highest number of leaves/plant; 295.3 and 247.7 for plants sprayed with seaweed extract comparing with the first and second cuts during both seasons, respectively. The interaction between the two investigated factors had a clear trend for all plant cuts in the first and second seasons where noted that the highest interaction values: 232.3 and 188.9 leaves/plant in the $1^{\text {st }}$ cut; 244.9 and 274.0 leaves/plant in the $2^{\text {nd }}$ cut and 392.4 and 278.0 leaves/plant in the third one 


\section{G.T. Mousa et al.}

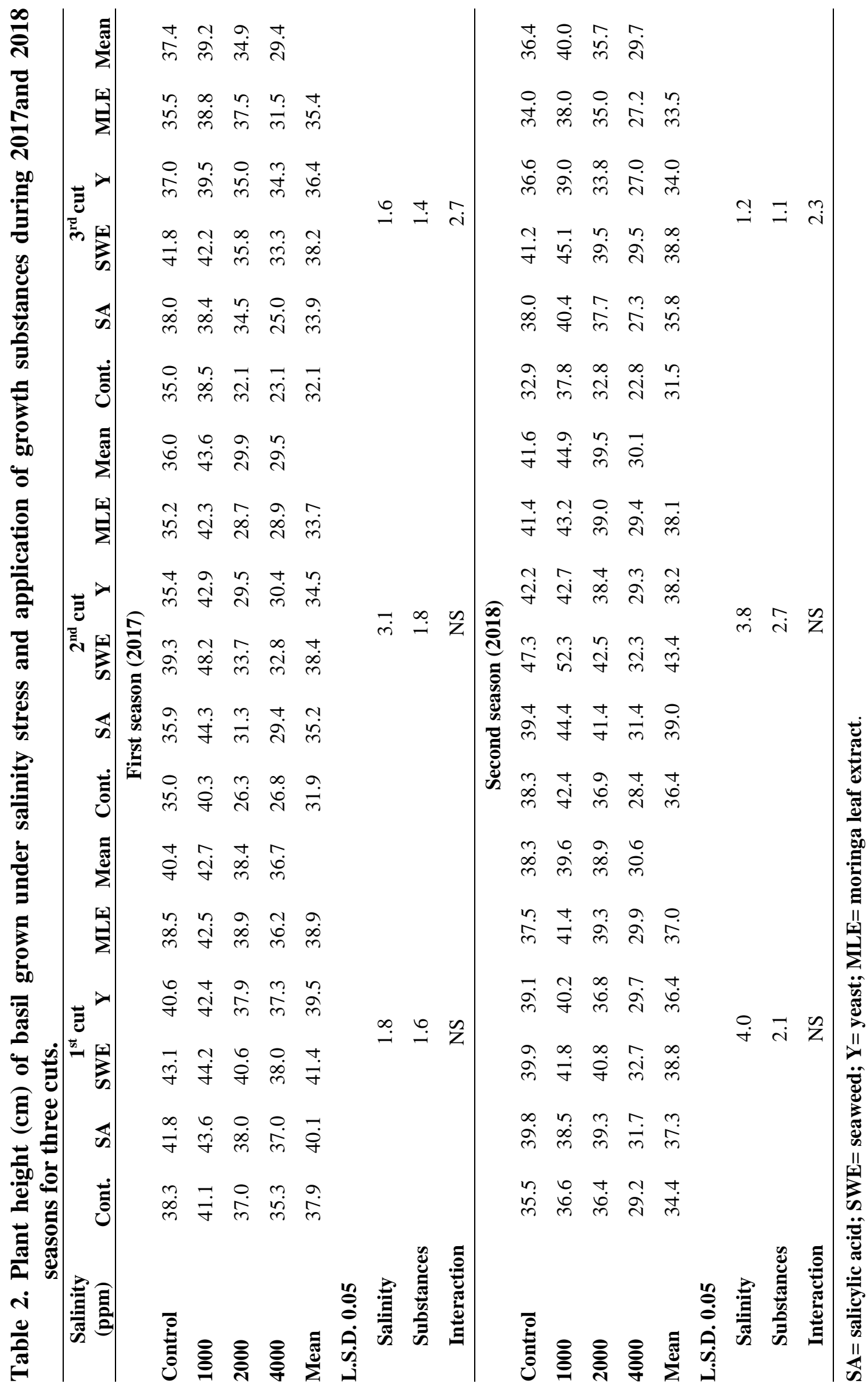




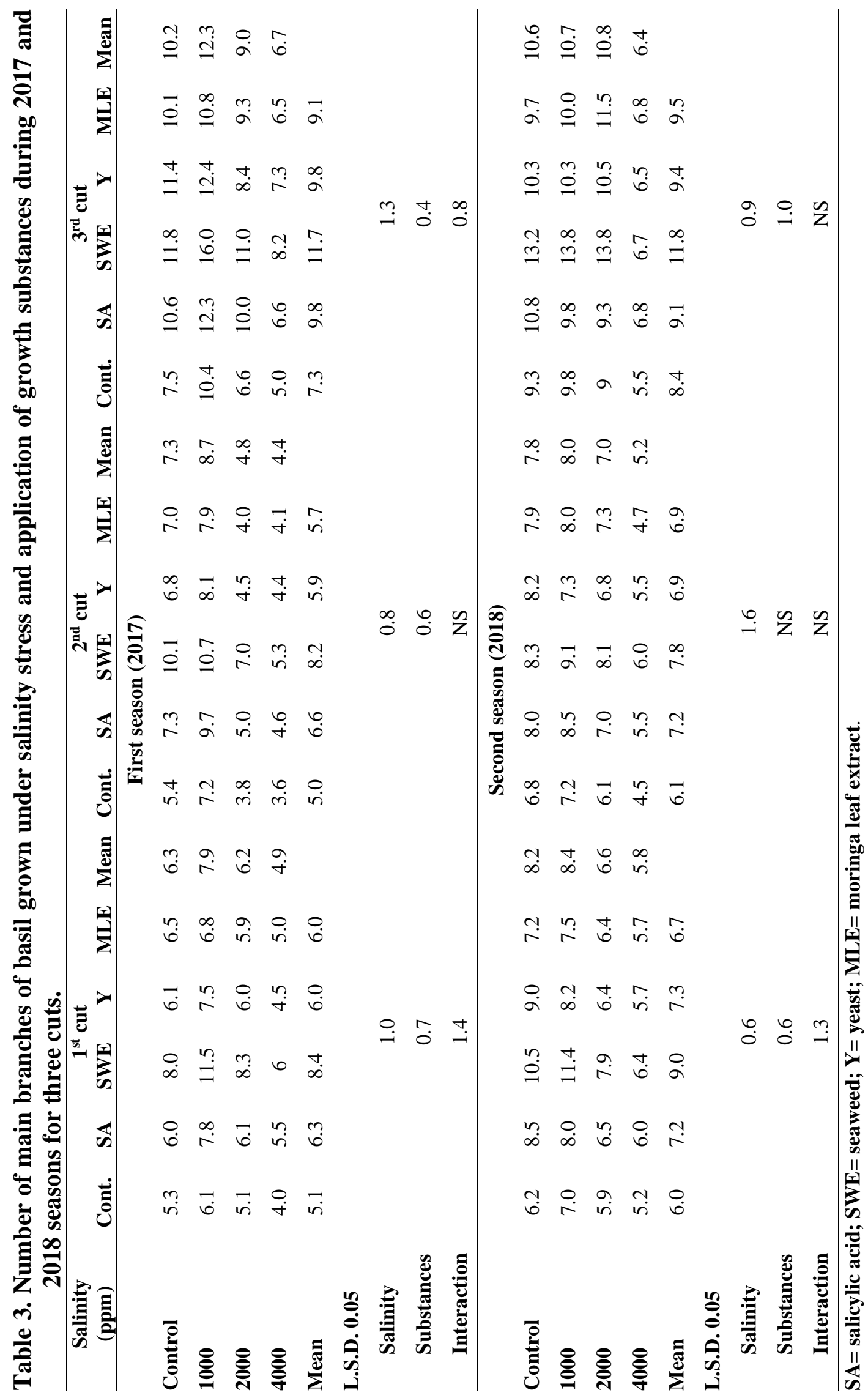




\section{G.T. Mousa et al.}

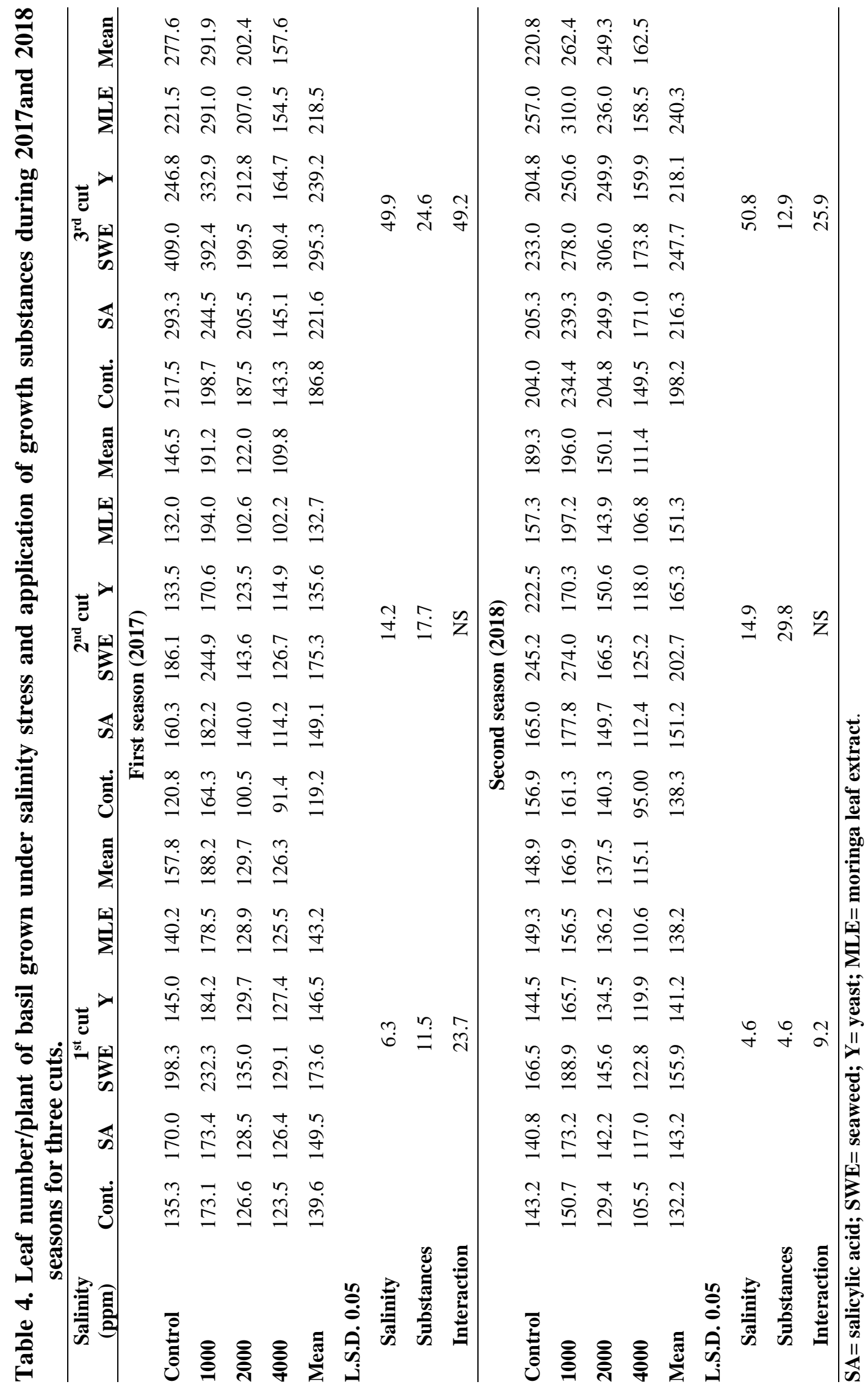


through the combination of $1000 \mathrm{ppm} \mathrm{NaCl}$ and seaweed extract.

It was clear from the results presented in Table (5) that fresh weight per plant was significantly increased for plants irrigated with 1000 ppm $\mathrm{NaCl}$ comparing with nonsalinized plants and the higher salinity levels (2000 and 4000 ppm NaCl). Second cut showed the highest values of basil fresh weight; 80.9 and $84.4 \mathrm{~g} /$ plant compared to the other ones in the first and second seasons, respectively.

Herb fresh weight was significantly affected by the seaweed more than the other treatments and control for all plant cuts during both seasons. The best combination which recorded the highest values of fresh weight/plant was noted with the seaweed treatment on basil plants grown under 1000 ppm of salinity for the second cut; 91.4 and $101.2 \mathrm{~g} /$ plant in both seasons, respectively.

Table (6) demonstrated that dry weight values per plant followed the same trend of those showed in fresh weight values per plant, where the highest dry weight;18.0 and $23.2 \mathrm{~g} /$ plant was recorded with the second cut of plants grown under 1000 ppm salinity stress and sprayed with seaweed extract during both seasons, respectively. In general, the obtained results showed that the dry weight of basil was highly increased with the low salinity level (1000 ppm $\mathrm{NaCl})$ and this result is considered very important to $O$. basilicum producers because the dry weight is the main products of basil. In addition, the second cut gave the greatest values of dry weight per plant than the first and third cut during both seasons.

Data presented in Table (7) clearly show that the leaf area values, plants grown under low salinity level (1000 ppm $\mathrm{NaCl})$ increased all cuts during both seasons. The highest values of leaf area (10.8 and 10.2 $\mathrm{cm}^{2}$ ) were recorded in the first cut of basil plants treated with seaweed extract in both seasons, respectively. Interaction values noticed that the greatest values of leaf area (15.0 and $14.7 \mathrm{~cm}^{2}$ ) were exhibited with applying seaweed to plants grown under $1000 \mathrm{ppm}$ of salinity for the $1^{\text {st }}$ and $2^{\text {nd }}$ seasons, respectively. These results are in agreement with those obtained by AbdelRahman et al. (2011). The suppressive effect of salinity may be caused by the photosynthetic and carbohydrates metabolism (Munns et al., 2006) and endogenous hormones levels (Javid et al., 2011).

On the other hand, the stimulatory effect of low salinity levels on vegetative growth of $O$. basilicum in this study was recorded by several authors as El-Shafey et al. (1991) and Abdel-Rahman et al. (2011), who recorded stimulatory effect of moderate salinity (1000 ppm) on growth of some plants, these may be due to improve shoot osmotic status as a result of increasing ions uptake. Simaei et al. (2011) attributed the dismal impacts of salinity on plant growth to an increase in reactive oxygen species which have an important role in damaging all classes of large biologically macromolecules including DNA and the generation of $\mathrm{H}_{2} \mathrm{O}_{2}$ and lipid hydro-peroxides which cause membrane changes. The obtained results showed that the 3\% foliar spray with seaweed extract resulted in an increase in all parameters for the vegetative growth of basil plants. The capability of seaweed on increasing these traits reflect the positive, physiological and biological roles of such natural compound (seaweed extract) which were described by many authors (Hamed, 2017). Adam (1999) indicated that seaweed extract is a natural source of organic and mineral nutrients, as well as a constituent of several natural growth regulators (GA, IAA and cytokinins) which augment cell division and fruits development. Seaweed extracts have to be recognized as excellent natural fertilizers and sources of organic matter, natural hormones, amino acid, B vitamins and different essential nutrients. Their stimulatory effects have to be soil conditioners and slow release fertilizer are not neglected (Planes-Ienyva et al., 2003). The utilization of seaweed extract augments 


\section{G.T. Mousa et al.}

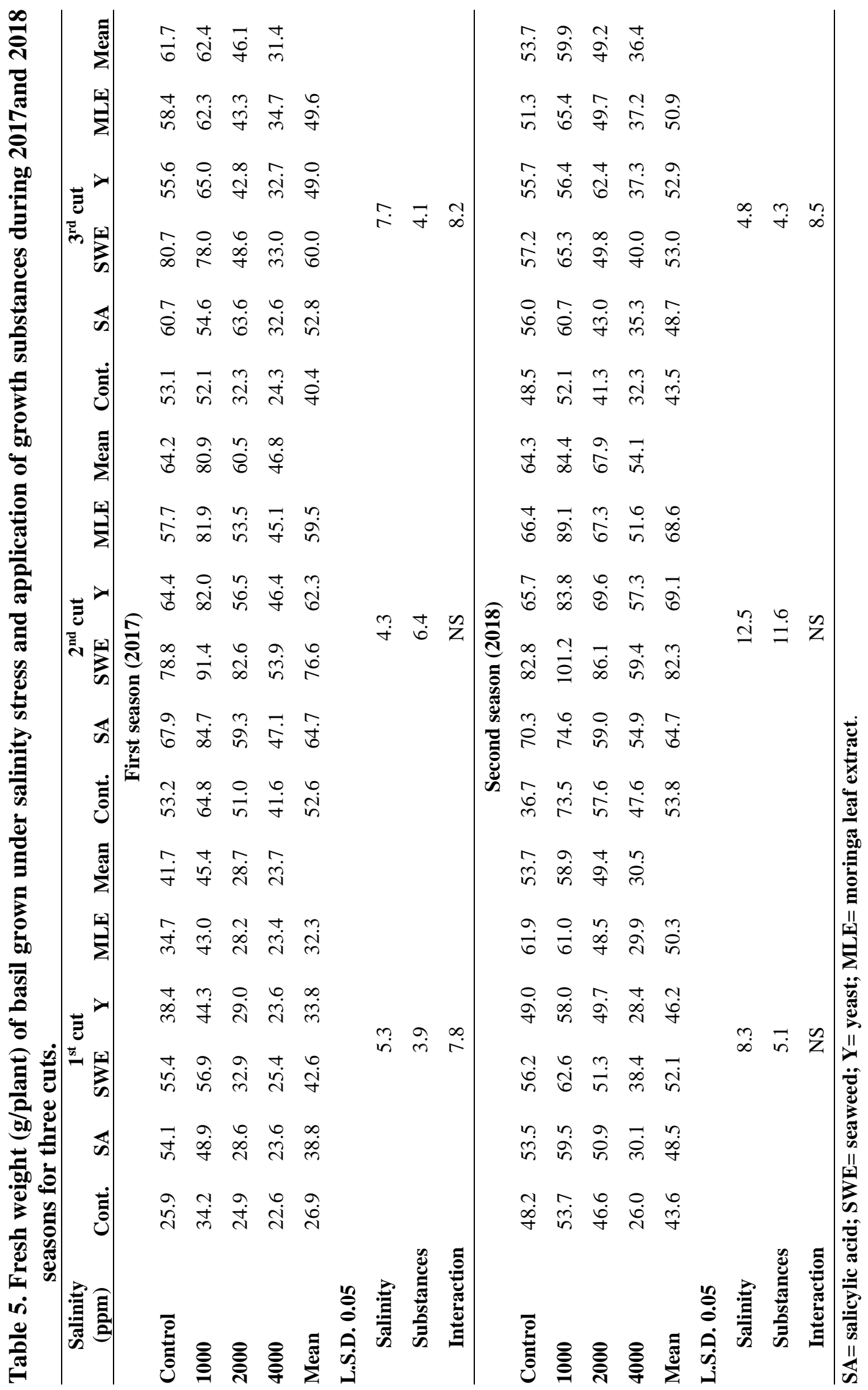




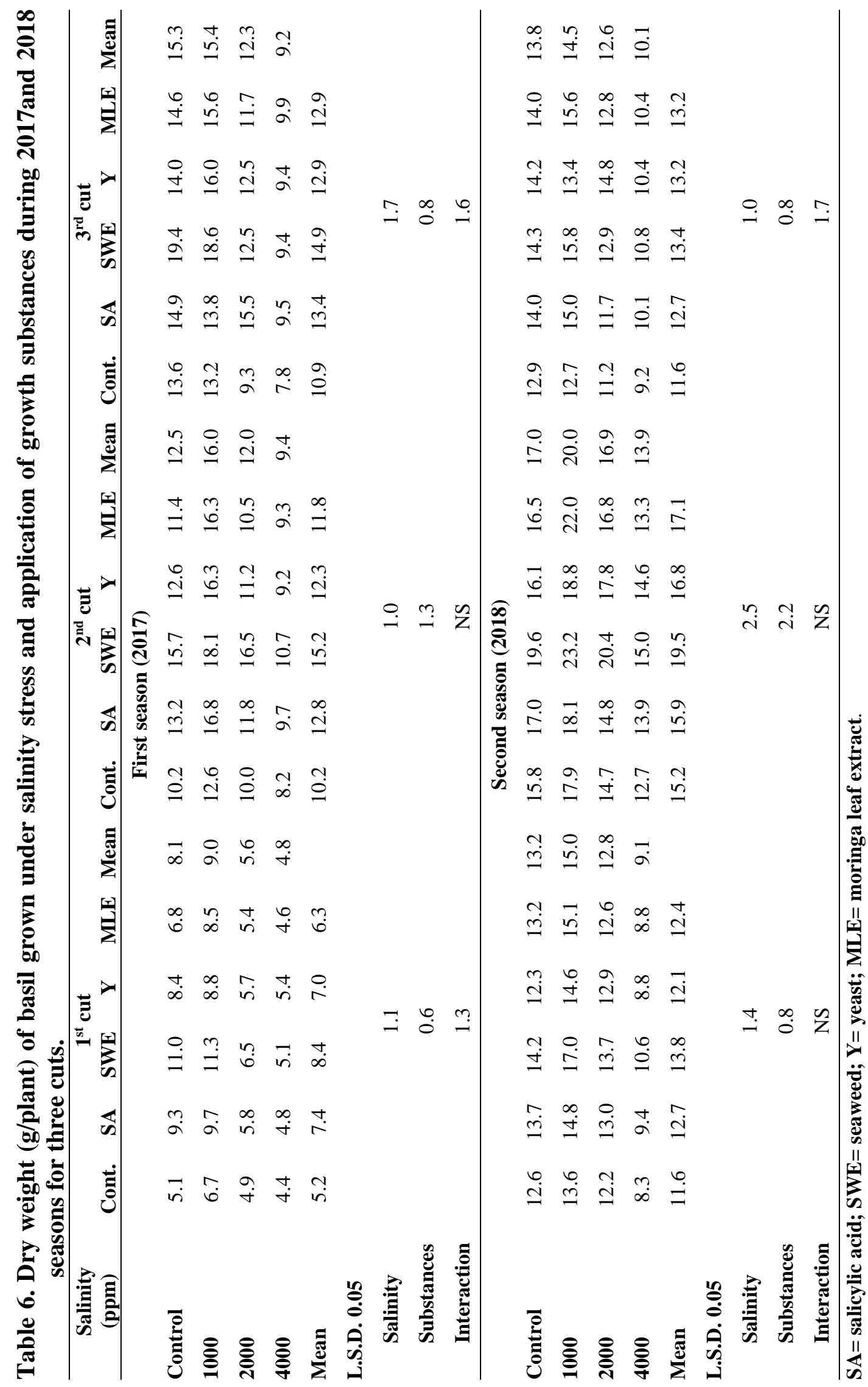




\section{G.T. Mousa et al.}

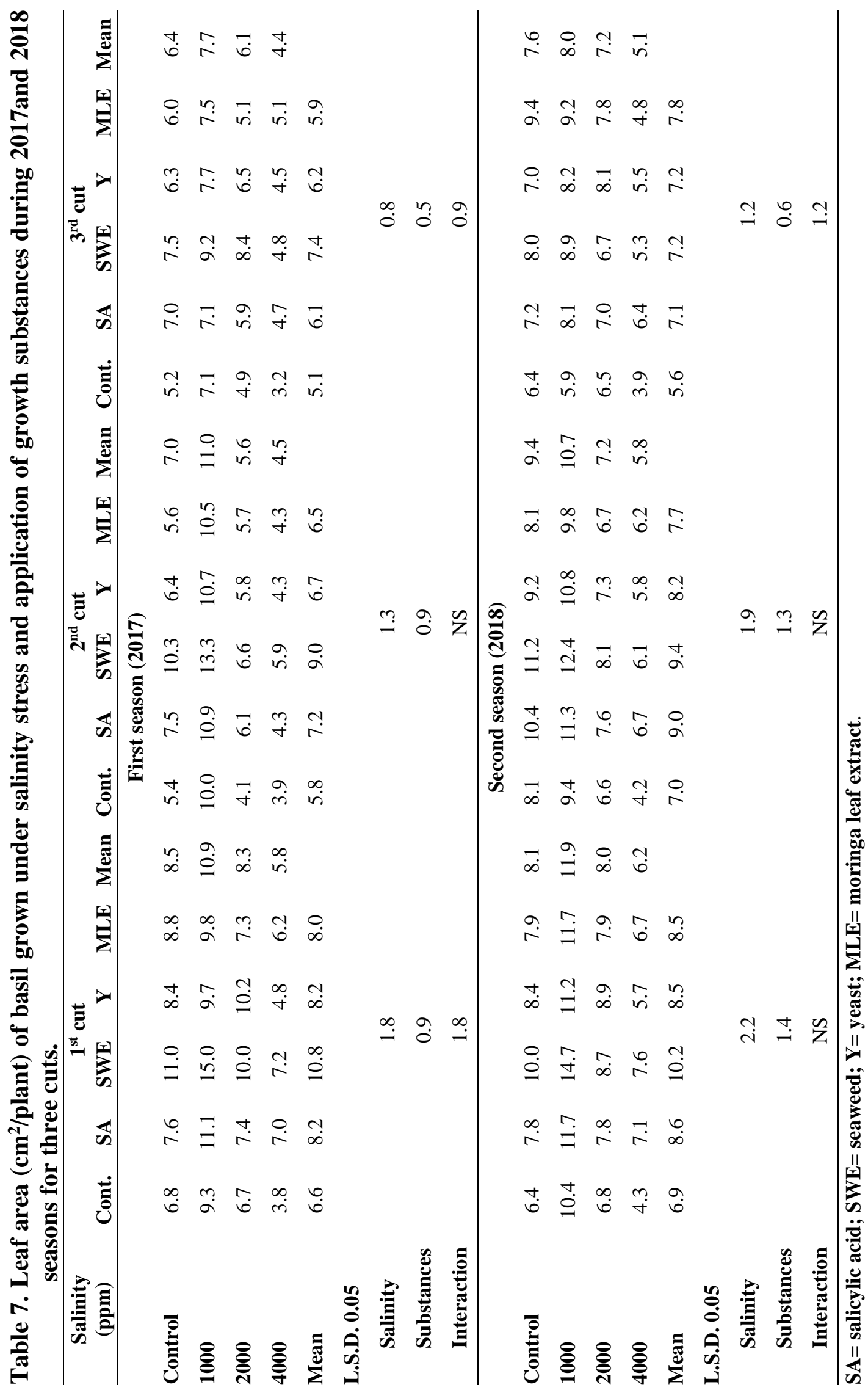


uptake of nutrients from the soil (Turan and Kose, 2004).

Data presented in Table (8) showed that volatile oil percentage of basil was highly affected with the low level of salinity (1000 ppm) where it recorded 3.1 and $3.8 \%$ in the first cut during both seasons, respectively. The highest percentages of volatile oil (3.2 and 3.7\%) were recorded in the plant treated with seaweed extract for the first cut during the first and second seasons, respectively. The best combination of seaweed with $1000 \mathrm{ppm} \mathrm{NaCl}$ produced the highest value of volatile oil (5.0\%) for the $1^{\text {st }}$ cut during the second season. Volatile oil yield/plant (Table, 9) exhibited a similar trend to those recorded in the oil percentage, where the data of second cut which showed superiority than the first and third cut for both factors as individually and in combined during the both seasons. The inhibitory effect of high level of salinity at the rate of 4000 ppm was also found by Kamal (1989) on chamomile, Hanafy (1989) on sweet marjoram. Also, the lower salinity level (1000 ppm NaCl) significantly increased oil percentage and yield in basil fresh leaves compared to control. The increase in oil \% and oil yield due to lower levels of salinity was also found by Hendawy and Khalid (2005). On the contrary, the higher salinity level (4000 ppm $\mathrm{NaCl})$ significantly decreased oil percentage and yield comparing with the other salinity levels. There are contradictory reports in the literature concerning the response of essential oil to salt stress. Salt stress decreased essential oil yield in Trachyspermum ammi (Ashraf and Orooj, 2006). This negative effect of salt stress on oil yield was also recorded for other medicinal plants, basil (Najafi et al., 2010), peppermint, pennyroyal, and apple mint (Aziz et al. 2008) and thyme (Belaqziz et al., 2009). Salinity may also affect the volatile oil accumulation indirectly through its influences on either net absorption or the division of assimilates among growth and differentiation processes (Charles et al., 1990).
It is clear from data presented in Tables (10 and 11) that chemical constituents of basil plant which expressed as active ingredients (total phenolics and free proline) were increased as a result of treating basil plants with salicylic acid under the higher salinity level (4000 ppm). On the other hand, the lower levels of these active ingredients were recorded in the plants sprayed with seaweed extracts under the lower salinity level (1000 ppm $\mathrm{NaCl})$ for all herb cuts. However, total phenols were increased with the high salinity level (4000 ppm $\mathrm{NaCl}$ ) compared to control and the other treatments which recorded 9.3 and $9.4 \mathrm{mg} / \mathrm{GAE} \mathrm{g}$ during both seasons, respectively at the first basil cut (Table, 10).

These results are agreement with those of Al-Amier and Craker (2007) on spearmint. They indicated that the content of phenols increased significantly along with increasing salinity levels. Cik et al. (2009) on Matricaria chamomilla found also that accumulation of phenolic acids (protocatechuic, chlorogenic and caffeic acids) were increased by increasing salinity level. Other studies published on Nigella sativa (Bourgou et al., 2010) and Mentha pulegium (Queslati et al., 2010) showed increase of phenols with saline treatment. The contents of some secondary plant products are significantly higher in plants grown under salt stress than in those cultivated under normal conditions (Omami et al., 2006). Phenolics have been regarded as a sensor for salt stress. This group consists of about 9000 compounds having diverse biological functions in plants. Some phenolic compounds can scavenge the reactive oxygen species (ROS) produced during abiotic stresses. Salt stress reduces the electron flow in the photosynthetic electron transport system and promotes oxidative stress via ROS production (Das and Roychoudhury, 2014). Higher plants produce compounds like phenolic acids, flavonoids and anthocyanidins to scavenge the harmful ROS. Salicylic acid production is a reaction to stress. Salicylic acid as a group of phenol compounds is an effective catalyst for the 


\section{G.T. Mousa et al.}

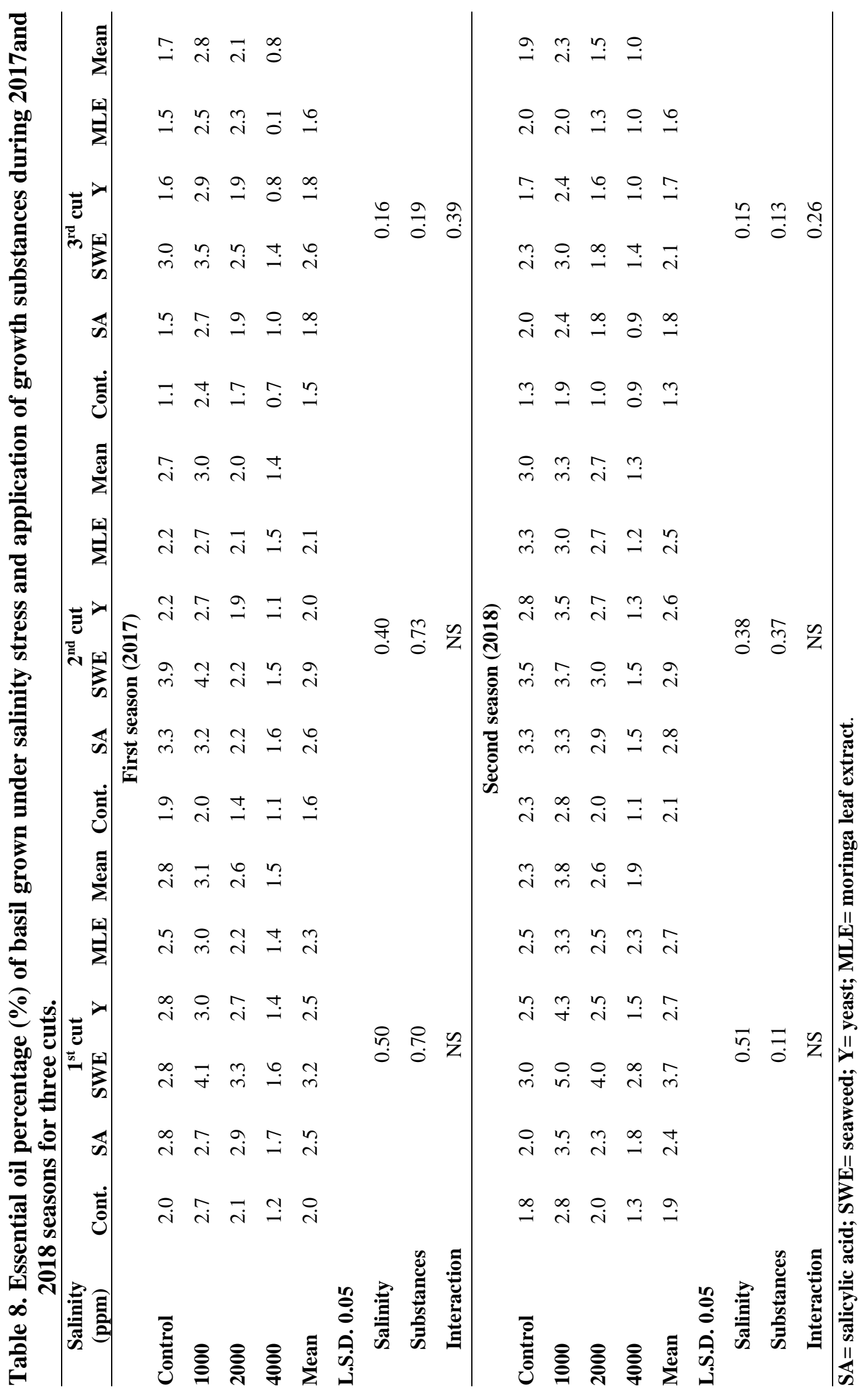




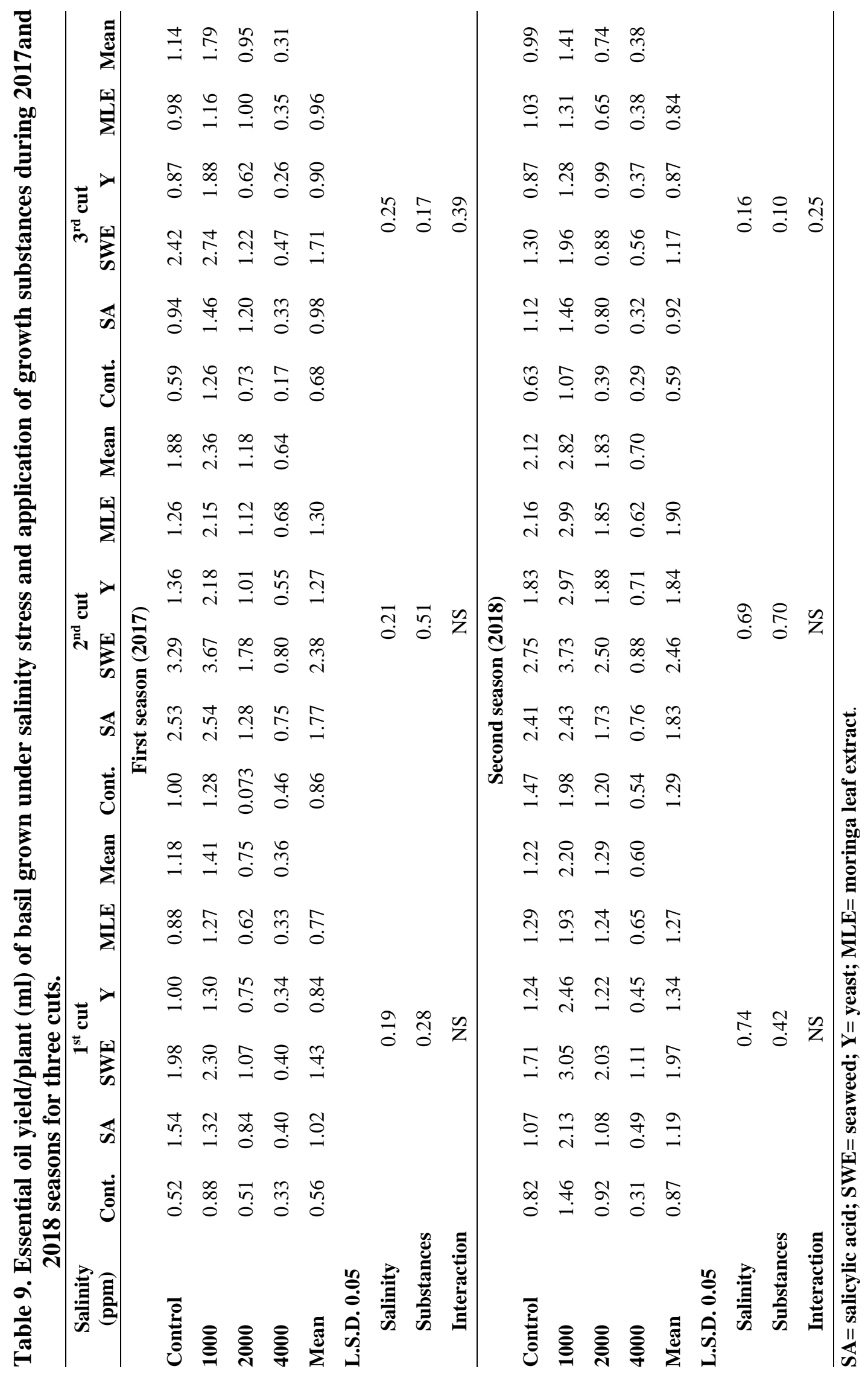




\section{G.T. Mousa et al.}

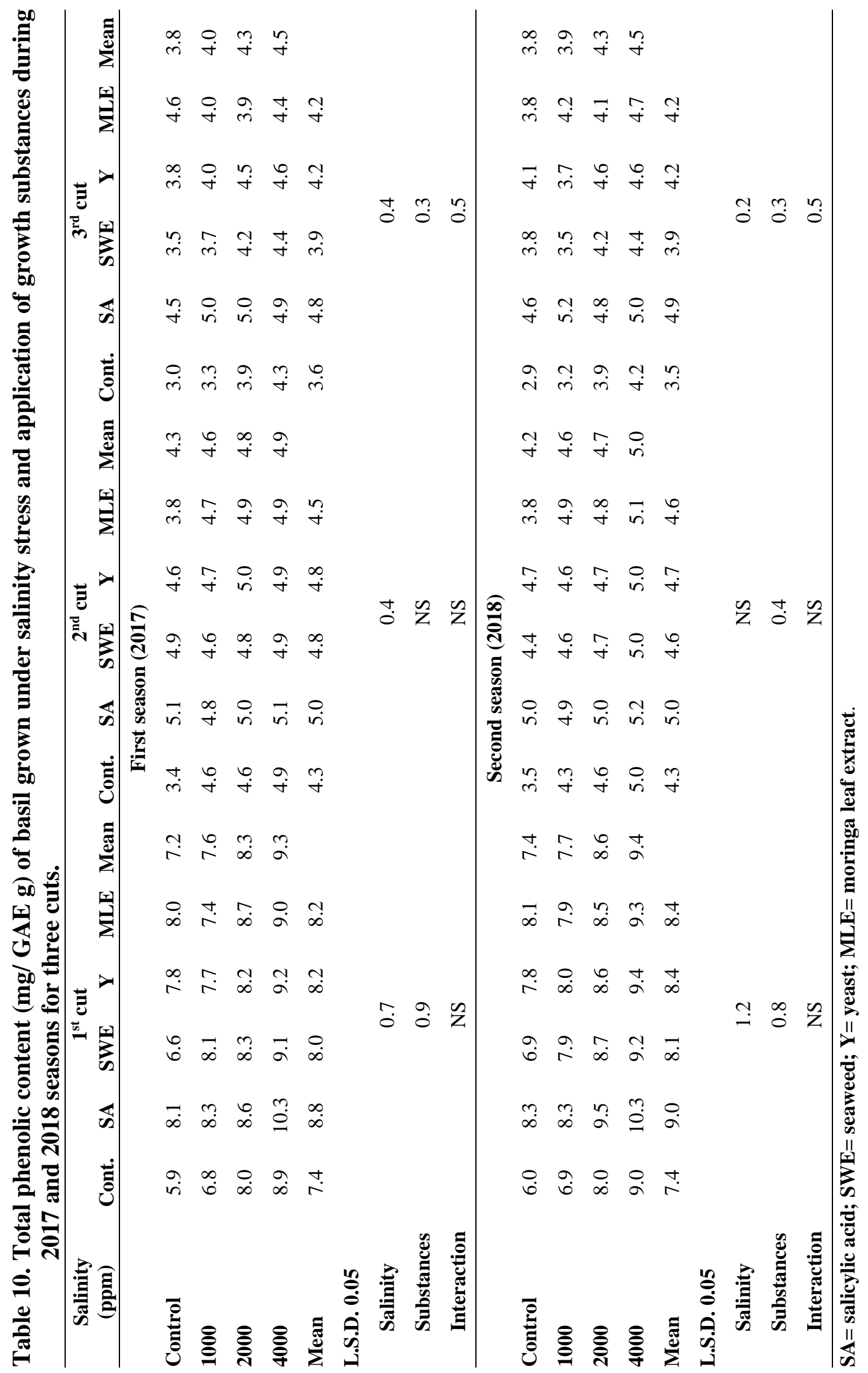




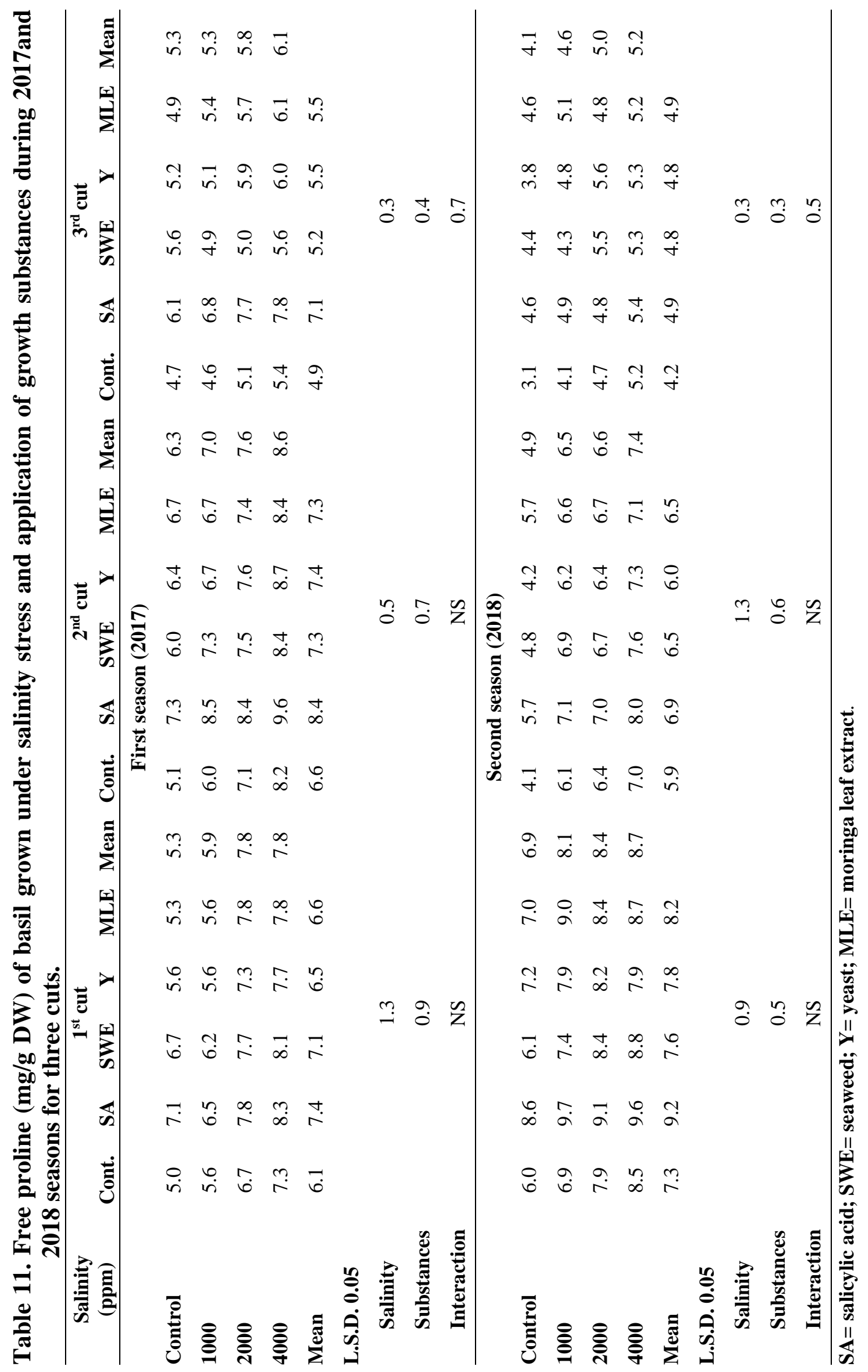




\section{G.T. Mousa et al.}

expression of genes involved in resistance that encode proteins associated with stress after being added to the external surface of most crops (Moradi and Rezvani, 2012).

Free proline enzymes were increased in the basil plants grown under $4000 \mathrm{ppm} \mathrm{NaCl}$ of salinity and recorded as the maximum at the second cut $(8.6 \mathrm{mg} / \mathrm{g} \mathrm{dw})$ during first season only and at the first cut $(8.7 \mathrm{mg} / \mathrm{g} \mathrm{dw})$ during second season only. Basil plants sprayed with salicylic acid showed the highest rate of free proline during both seasons (Table, 11). These results are in harmony with those of Türkan and Demiral (2009). Proline accumulation is a wellknown measure adopted for alleviation of salinity stress (Ben et al., 2010). Intracellular proline which is accumulated during salinity stress not only provides tolerance towards stress but also acts as an organic nitrogen reserve during stress recovery. Proline is synthesised either from glutamate or ornithine. In somatically stressed cell glutamate functions as the primary precursor. The biosynthetic pathway comprises two major enzymes, pyrroline carboxylic acid synthetase and pyrroline carboxylic acid reductase. Both these regulatory steps are used to overproduce proline in plants (Sairam and Tyagi, 2004). It functions as an $\mathrm{O}_{2}$ quencher thereby revealing its antioxidant capability. Ben et al. (2010) observed that proline supplements enhanced salt tolerance in olive (Olea europaea) by amelioration of some antioxidative enzyme activities, photosynthetic activity, and plant growth and the preservation of a suitable plant water status under salinity conditions.

\section{REFERENCES}

Abdel-Rahman, S.S.A.; Abdel-Kader, A.A.S. and Khalilm S.E. (2011). Response of three sweet basil cultivars to inoculation with Bacillus subtilis and Arbuscular mycorrhizal fungi under salt stress conditions. Nature and Sci., 9(6):93-111.
Adam, M. (1999). The promotive effect of Cyanobacterium Nostoc Seaweed. J. of Food Biochemistry, 35(2):513-523.

Al-Amier, H. and Craker, L.E. (2007). In Vitro selection for stress tolerant spearmint. Reprinted from: Issues in New Crops and New Uses, Janick, J. and Whipkey, A. (eds.). ASHS Press, Alexandria, VA., pp. 306-310.

Al-Karaki, G.N. (2001). Germination, sodium and potassium concentrations of barley seeds as influenced by salinity. J. Plant Nutr., 24:511-522.

Amer, S.S.A (2004). Growth, green pods yield and seeds yield of common bean (Phaseolus vulgaris L.) as affected by active dry yeast, salicylic acid and their interaction. J. Agric Sci. Mansoura Univ., 29(3):1407-1422.

Ashraf, M. and Orooj, A. (2006). Salt stress effects on growth, ion accumulation and seed oil concentration in an arid zone traditional medicinal plant ajwain (Trachyspermum ammi L. Sprague). J. Arid Environ., 64:209-220.

Aziz, E.E, Al-Amier, H. and Craker, L.E. (2008). Influence of salt stress on growth and essential oil production in peppermint, pennyroyal, and apple mint. J. Herbs Spices Med. Plants., 14(1 \& 2):77-87.

Bagherifard, A.; Bagheri, A.; Sabourifard, H.; Bagherifard, G. and Najar, M. (2015). The effect of salicylic acid on some morphological and biochemistry parameters under salt stress in herb artichoke (Cynara scolymus L.). Res. J. Fisheries and Hydro., 10(10):745-750.

Bates, L.S. (1973). Rapid determination of free proline for water stress studied. Plant and Soil, 39:205-207.

Battacharyya, D.; Babgohari, M.Z.; Rathor, P.; and Prithiviraj, B. (2015). Seaweed extracts as biostimulants in horticulture. Sci. Hortic., 30(196):39-48. 
Belaqziz, R.; Romane, A. and Abbad, A. (2009). Salt stress effects on germination, growth and essential oil content of an endemic thyme species in Morocco (Thymus maroccanus Ball.). J. Applied Sci. Sci. Res., 5(7): 858-863.

Ben Ahmed, C.B.; Ben Sensoy, R.S.; Boukhriss, M. and Ben Abdullah, F. (2010). Exogenous proline effects on photosynthetic performance and antioxidant defense system of young olive tree. J. Agric. and Food Chem., 58(7):4216-4222.

Bhaskar, N. and Miyashita, K. (2005). Lipid composition of Padina tetratomatica (Dictyotales pheophyta), a brown seaweed of the West Coast of India. Ind. J. Fisheries., 52(3):263-268.

Bourgou, S.; Kchouk, M.E.; Bellila, A. and Marzouk, B. (2010). Effect of salinity on phenolic composition and biological activity of Nigella sativa. Acta Hort., 853:57-60.

Charles, D.J.; Joly, R.J. and Simon, J.E. (1990). Effect of osmotic stress on the essential oil content and composition of peppermint. Phytochem., 29:2837-2840.

Cik, J.K.; Klejdus, B.; Hedbavny, J. and Bačkor, M. (2009). Salicylic acid alleviates $\mathrm{NaCl}$-induced changes in the metabolism of Matricaria chamomilla plants. Ecotoxicology, 18(5):544-554.

Da Silva, T.I.; Filho, J.S.M.; Gonçalves, A.C.M.; de Sousa, L.V.; de Moura, J.G.; Dias, T.J.; Aizarro, J.C.; Pereira, W.E. and Mendonça, R.M.N. (2018). Salicylic acid effect on Ocimum basilicum L. during growth in salt stress and its relationship between phytomass and gas exchange. J. Exp. Agric. Int., 22(4):1-10.

Das, K. and Roychoudhury, A. (2014). Reactive oxygen species (ROS) and response of antioxidants as ROSscavengers during environmental stress in plants. Front Env. Sci., 2:53. https://doi.org/10.3389/fenvs.2014.00053
Delavari, P.M.; Baghizadeh, A.; Enteshari, S.H.; Kalantari, M.; Yazdanpanah, K.A. and Mousavi, E.A. (2010). The effects of salicylic acid on some of biochemical and morphological characteristic of Ocimum basilicucm under salinity stress. Australian J. Basic and App. Sci., 4(10):4832-4845.

EL-Shafey, S.A.; Awad, A.E.; Meawad, A.A. and Elshaer, M. (1991). Effects of saline water irrigation on the growth, oil yield, plant pigments and chemical composition of sweet basil plants. Zagazig J. Agric. Res., 18 (6):2211-2220.

Evans, W.C. (2001). Trease and Evans Pharmacognosy. $4^{\text {th }}$ Ed. WB Saunders Company LTD., London, pp. 48.

Greenway, H. and Munns, R. (1980). Mechanism of salt tolerance in nonhalophytes. Ann. Rev. Plant Physiol., 31:149-190.

Guenther, E. (1961). The Essential Oils. New York, London: Dvan Nostrand Co., pp. 111.

Hamed, M.H.H. (2017). Response of Anise Plants to Some Different Agricultural Treatments. M.Sc. Thesis, Fac. Agric., Al-Azhar Univ., Assiut Branch, Egypt., $132 \mathrm{p}$.

Hamouda, A.M.A.; Hendi, D.M.G. and Abu El-Leel, O.F. (2012). Improving basil growth, yield and oil production by Aloe vera extract and active dry yeast. Egypt. J. Hort., 39(1):45-71.

Hanafy, M.S. (1989). Effect of Chemical Fertilization and Salinity on Production of Herb and Essential Oil of Majoram Plants, Majorana hortensis. Ph.D. Thesis., Fac. Agric., Cairo Univ., Egypt, $164 \mathrm{p}$.

Hassan, P.M.B.; Mohair, G.R. and Tabatabaei, S.J. (2010). Inflorescence and leaves essential oil composition of hydroponically grown Ocimum basilicum L. J. Serbian Chem. Soci., 75(10):13611368. 


\section{G.T. Mousa et al.}

Hassanein, R.A.; Abdelkader, A.F. and Faramawy, H.M. (2019). Moringa leaf extracts as biostimulants-inducing salinity tolerance in the sweet basil plant. Egypt. J. Bot., 59(2):303-318.

Hendawy, S.F. and Khalid, K.h.A. (2005). Response of sage (Salvia officinalis L.) plants to zinc application under different salinity levels. J. Appl. Sci. Res., 1(2):147-155.

Jackson, M.L. (1973). Soil Chemical Analysis. Prentice-Hall, Inc. Englewood Cliffs, N.J. New Delhi, India, 498 p.

Javid, M.G.; Sorooshzadeh, A.; Modarres, F.; Sanavy, S. and Allahdadi, I. (2011). The role of phytohormones in alleviating salt stress in crop plants. Australian J. Crop Sci., 5:726-734.

Kamal, H.M. (1989). Histological Study on Chamomile Plant. M.Sc. Thesis, Fac. Agric., Zagazig Univ., Egypt, 132 p.

Karalija, E. and Parić, A. (2017). Effects of salicylic acid foliar application on growth and antioxidant potential of basil (Ocimum basilicum L.). Biologica Nyssana, 8(2):145-150.

Koba, K.; Poutouli, P.W.; Raynaud, C.; Chaumont, J.P. and Sanda, K. (2009). Chemical composition and antimicrobial properties of different basil essentials oils chemotypes from Togo. Bangladesh J. Pharmacol, 4:1-8.

Mohamed, Y.F.Y.; Zewail, R.M.Y., and Ghatas, Y.A.A. (2016). The role of boron and some growth substances on growth, oil productivity and chemical characterization of volatile oils in basil (Ocimum basilicum, L.) cv. Genovese plant. J. Hort. Sci. Ornamental Plants, 8(2):108-118.

Mondal, H.K. and Kaur, H. (2017). Effect of salt stress on medicinal plants and its amelioration by plant growth promoting microbes. Inter. J. Bio-Resource and Stress Management, 8(2):316-326.
Moradi, H. and Rezvani, P. (2012). Effect of seed priming by salicylic acid on salt stress on germination and growth characteristics of fennel seedling. Agric. Res. in Iran, 8(3):483-489.

Moyo, B.; Masika, P.J.; Hugo, A. and Muchenje, V. (2011). Nutritional characterization of Moringa (Moringa oleifera Lam) leaves. Afr. J. Biol., 10(60):12925-12933.

Munns, R.; Jwmes, R.A. and Lauchli, A. (2006). Approaches to increasing the salt tolerance of wheat and other cereals. J. Exp. Bot., 57(5):1025-1043.

Najafi, F.; Khavari-Nejad, R.A. and Ali, M.S (2010). The effects of salt stress on certain physiological parameters in summer savory (Satureja hortensis L.) plants. J. Stress Physiol. Biochem., 6(1):13-21.

Nassar, M.A.; El-Segai, M.U. and Azoz, S.N. (2015). Influence of foliar spray with yeast extract on vegetative growth, yield of fresh herb, anatomical structure and composition of volatile oil and seed yield components of basil plant (Ocimum basilicum L.). Inter. J. Adv. Res., 3(10):978-993.

Omami, E.N.; Hammes, P.S. and Robbertse, P.J. (2006). Differences in salinity tolerance for growth and water-use efficiency in some amaranth (Amaranthus spp.) genotypes. New Zealand J. Crop Hort. Sci., 34:11-22.

Patil, S.B. and Bodhe, S.K. (2011). Betel leaf area measurement using image processing. Inter. J. Comp. Sci. Engineering, 3(7):2656-2660.

Patrick, D.J. (2015). Plant biostimulants: definition, concept, main categories and regulation. Sci. Hort., 196:3-14.

Phiri, C. (2010). Influence of Moringa oleifera leaf extracts on germination and early seedling development of major cereals. Agric. Biol. J. N Amer., 1(5):774-777. 
Planes-Ienyva, M.; Tery, I.A.; Figueroa, S.I. and Lores, A. (2003). Biofertilization as a tool of biotechnology for sustainable agriculture. Alimentaria, 40(346):61-65.

Queslati, S.; Karray-Bouraoui, N.; Attia, H.; Rabhi, M.; Ksouri, R. and Lachaal, M. (2010). Physiological and antioxidant responses of Mentha pulegium (pennyroyal) to salt stress Acta. Physiol. Plant., 32(2):289-296.

Sairam, R.K. and Tyagi, A. (2004). Physiology and molecular biology of salinity stress tolerance in plants. Current Sci., 86(3):407-421.

Shehata, A.M. and Nosir, W.S.E. (2019). Response of sweet basil plants (Ocimum basilicum, L.) grown under salinity stress to spraying seaweed extract. The Future Jour. Biol., 2(1):16-28.

Simaei, M.; Khavari-Nejad, R.A.; Saadatmand, S.; Bernard, F. and Fahimi, F. (2011). Interactive effects of salicylic acid and nitric oxide on soybean plants under $\mathrm{NaCl}$ salinity. Russian Jour. Plant Physiology, 58(5):783-390.
Singh, M.P. and Panda, H. (2005). Medicinal Herbs with Their Formulations. Daya Publishing House, Delhi, pp. 607-610.

Snedecor, G.W. and Cochran, W.G. (1989). Statistical Methods, Eighth Edition, Iowa State University Press. Ames, Iowa, 503 p.

Srivastava, P. and Kumar, R. (2015). Soil salinity, a serious environmental issue and plant growth promoting bacteria as one of the tools for its alleviation. Saudi J. Biol. Sci., 22:123-131.

Turan, K. and Kose, M. (2004). Seaweed extract improves copper uptake of grapevine (Vitis vinifera). Acta. Agric. Scandinavica, Section B Soil and Plant Sci., 54:213-220.

Türkan, I. and Demiral, T. (2009). Recent developments in understanding salinity tolerance. Environ. Exp. Bot., 67:2-9.

Vasco, C.; Ruales, J. and Kamal-Eldin, A. (2008). Phenolic compounds and antioxidant capacities of major fruits from Ecuador. Food Chem., 111:816823.

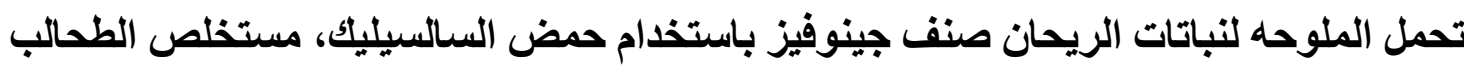

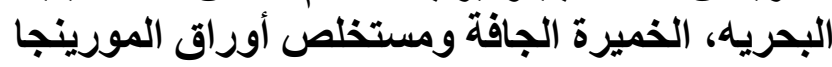 \\ جمال طه موسى ، سيد شحاته عابدين عبدالرحمن ، عصام يوسف عبدالحفيظ ، نسمه مصطفى كامل رسلان

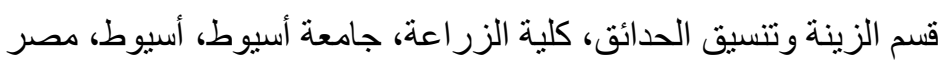

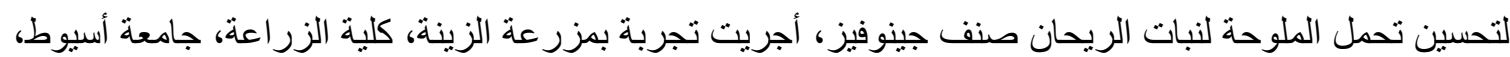

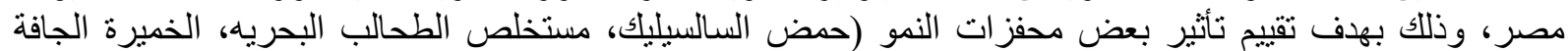

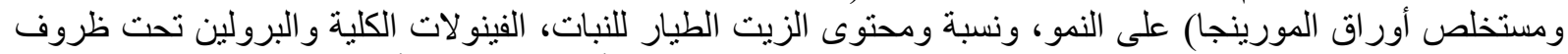

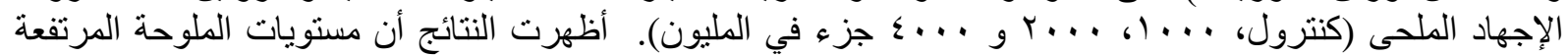

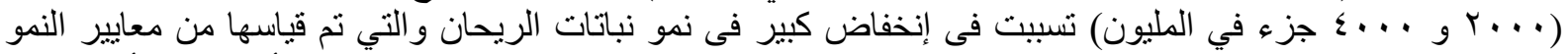

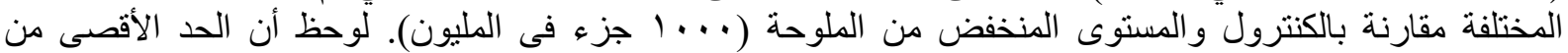

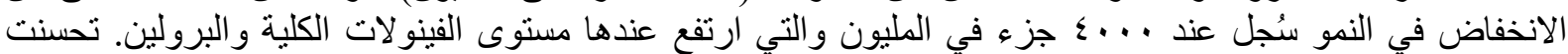

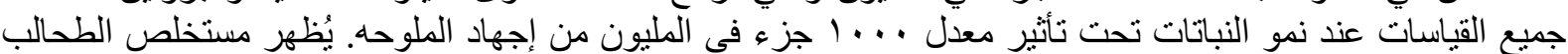

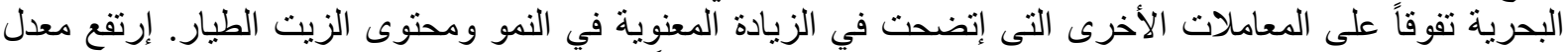

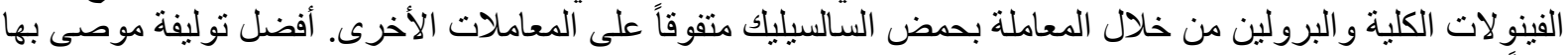

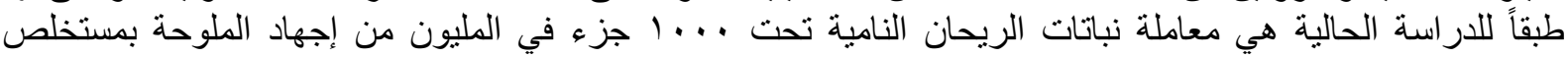

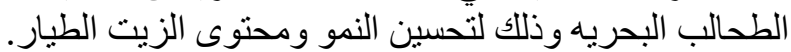

